\title{
Sport Law Amici: Impact, Opportunity, and Scholarship
}

\author{
Ryan M. Rodenberg*
}

\section{Introduction}

The knowledge and ability to research, write, and file a United States Supreme Court amicus brief - a legal document submitted by a third party in an on-going lawsuit - is an important skill for sport law scholars to possess. ${ }^{1}$ With high-profile sport-related disputes routinely being litigated, professors' expertise in a discrete issue can potentially assist the Court in its decision-making. ${ }^{2}$ Indeed, Supreme Court Rule 37 states that "an amicus curiae brief that brings to the attention of the Court relevant matter not already brought to its attention by the parties may be of considerable help to this Court." ${ }^{3}$ However, Supreme Court Rule 37 also makes clear that "an amicus curiae brief that does not serve this purpose burdens the Court, and its filing is not favored."

In 2014, I filed a co-authored amicus brief in the first incarnation of the $N C A A$, NBA, NFL, NHL \& MLB v. Governor Christie, et al. ${ }^{5}$ sports betting case. Two years later, I filed a solo-authored amicus brief in the same case when it made its way back to the Supreme Court. ${ }^{6}$ Other professors have done the same in earlier sport law disputes that reached the Court. In 2000, Anita Moorman and Lisa Pike Masteralexis filed a merits stage amicus brief in Martin v. PGA Tour, an Americans

\footnotetext{
${ }^{*}$ Ryan A. Rodenberg, JD, PhD, is an associate professor in the Department of Sport Management at Florida State University; email: rrodenberg@fsu.edu

${ }^{1}$ The phrase "amicus curiae" is Latin and means "friend of the court."

${ }^{2}$ Researchers Flango, Bross, and Corbally summarized that: "[a]micus briefs can affect the perspective from which an appellate court views a case by showing how the decision is important to others not party to the case, by providing additional information and expertise that parties may not have, and by developing legal arguments that parties sometimes cannot.” Victor E. Flango, Donald C. Bross, \& Sarah Corbally, Amicus Curiae Briefs: The Court's Perspective, 27 Just. Sys. J. 180 (2006).

${ }^{3}$ Supreme Court Rule 37.

${ }^{4}$ Id.

${ }^{5}$ Brief for Amici Curiae Ryan M. Rodenberg, Anastasios Kaburakis, \& John T. Holden in Support of Petitions for Writ of Certiorari, Christie, et al. v. NCAA, et al., 134 S.Ct. 2866 (Mar. 14, 2014) (Nos. 13-967, 13-979, 13-980).

${ }^{6}$ Brief of Professor Ryan M. Rodenberg as Amicus Curiae in Support of Petitions for Writ of Certiorari, Christie, et al. v. NCAA, et al., 2017 U.S. LEXIS 702 (Nov. 4, 2016) (No. 16-476, 16-477).
} 
with Disabilities Act case. 7 In 2009, two groups of economists filed amicus briefs on different sides in a prominent antitrust case, American Needle v. NFL, et al. ${ }^{8}$

Amicus filings by sport law professors should be valued as scholarship. A well-done amicus brief likely includes just as much legal research as any academic article on the same topic. Such an amicus brief also has the potential to affect sport law policy moving forward. While an amicus brief represents a unique opportunity for research, there are several nuts-and-bolts requirements that go along with a Supreme Court amicus filing. A summary is provided here.

At the certiorari stage, amici must position their brief either in support of the pending cert petition or in opposition of the cert petition. ${ }^{9}$ If the Supreme Court grants cert, then amici have three choices for a merits stage amicus brief: (i) in support of petitioner; (ii) in support of respondent; or (iii) in support of neither party..$^{10}$ Amicus briefs in support of neither party are filed when amici furthers one or more legal arguments providing an alternative basis for the Supreme Court to decide the case beyond the arguments already enunciated by the parties. ${ }^{11}$

In addition to filing certiorari stage and merits stage amicus briefs, Supreme Court rules also allow amici to take part in oral argument. ${ }^{12}$ Supreme Court Rule 28.7 allows amici to take part in oral argument "only in the most extraordinary circumstances" and must "provide assistance to the Court not otherwise available." ${ }^{\prime 3}$ Such allowances are rare, especially for non-governmental amici. On several occasions during each term, the Solicitor General is allocated oral argument time to articulate the government's position on a case. Sometimes the Solicitor General's oral argument time is taken from the two parties. Other times, the Solicitor General's oral argument slot is added in addition to the normal time allocation for the petitioner and respondent.

\footnotetext{
${ }^{7}$ Anita Moorman \& Lisa Pike Masteralexis, Writing an Amicus Curiae Brief to the United States Supreme Court, PGA Tour, Inc. v. Martin: The Role of the Disability Sport Community in Interpreting the Americans with Disabilities Act, 11 J. Legal Aspects Sport 285 (2001). In addition to the amicus brief filed by Moorman and Masteralexis, the United States also filed an amicus brief in the PGA Tour v. Martin case. See Brief for the United States as Amicus Curiae Supporting Respondent, PGA Tour v. Martin, 532 U.S. 661 (Dec. 2000) (No. 00-24).

${ }^{8}$ See Brief of Economists as Amicus Curiae Supporting Petitioner, American Needle v. National Football League, et al. (Sept. 24, 2009); Brief of Economists as Amici Curiae in Support of Respondents, American Needle v. National Football League, et al., 560 U.S. 183 (Nov. 24, 2009) (No. 08-661).

${ }^{9}$ Supreme Court Rule 37. Certiorari stage amicus briefs are limited to 6,000 words and must be filed with cream-colored cover sheets.

${ }^{10} I d$. Merits stage amicus briefs are limited to 9,000 words. Those filed in support of the petitioner or in support of neither party have light green cover sheets. Those filed in support of respondent have dark green cover sheets.

${ }^{11} I d$.

${ }^{12}$ Supreme Court Rule 21 and 28.

${ }^{13}$ Supreme Court Rule 28.7.
} 
The same Supreme Court rule allowing the Solicitor General to ask for oral argument time also provides private, non-governmental amici the opportunity to file a motion "for leave to participate in oral argument as amicus curiae and for divided argument." 14 One of the most recent examples of such a motion was filed by Stephen Sachs in Atlantic Marine, a civil procedure case involving the interpretation of a forum selection clause. ${ }^{15}$ After filing a merits stage amicus brief in support of neither party, Sachs filed a motion seeking oral argument time on August 23, 2013. ${ }^{16}$ Within days, both petitioner and respondent filed motions opposing Sachs. ${ }^{17}$ Respondent J-Crew Management, Inc. posited that "Professor Sachs's participation in oral argument would serve only to distract the Court and parties from the issues that must be decided in this case." ${ }^{\prime 18}$ On October 1, 2013, the Supreme Court issued an order denying Sachs's motion, but instructed the parties to "be prepared to address at oral argument the arguments raised in the brief of Professor Stephen E. Sachs as amicus curiae in support of neither party." 19 In the National Law Journal, journalist Tony Mauro described the Supreme Court's order as a "rare homework assignment." ${ }^{20}$ During October 9, 2013, oral argument in the case, several justices referenced Sachs by name in the course of questioning attorneys for both sides. ${ }^{21}$

\footnotetext{
${ }^{14}$ See e.g., Motion of Professor Stephen E. Sachs for Leave to Participate in Oral Argument as Amicus Curiae and for Divided Argument, Atlantic Marine Const. v. U.S Dist. Court, et al., 571 U.S. 134 S.Ct. 568 (Aug. 23, 2013) (No. 12-929).

${ }^{15} \mathrm{Id}$. Professor Sachs explained his motivation for interjecting into the case as amici: "I also think it's the job of academics to stay connected with what's going on in the courts and to be able to say, 'Hey, this will actually have some effect beyond this case that might not have been immediately apparent just based on the parties' briefs,' he said." Sachs' Supreme Court Amicus Brief 'In Support of Neither Party" on Procedural Point Gets Noticed, Duke University School of Law (Oct. 1, 2013), https://law.duke.edu/news/sachs-supreme-court-amicus-brief-support-neither-party-procedural-point-gets-noticed/.
}

${ }^{16} I d$.

${ }^{17}$ See Response in Opposition to Motion of Prof. Stephen E. Sachs to Participate in Oral Argument as Amicus Curiae and for Divided Argument, Atlantic Marine Const. v. U.S Dist. Court, et al., 571 U.S. ___, 134 S.Ct. 568 (Aug. 26, 2013) (No. 12-929); Amended Response in Opposition to Professor Stephen E. Sachs's Motion for Leave to Participate in Oral Argument as Amicus Curiae for Respondent J-Crew Management, Inc., Atlantic Marine Const. v. U.S Dist. Court, et al., 571 U.S. 134 S.Ct. 568 (Sept. 11, 2013) (No. 12-929).

${ }^{18} I d$.

${ }^{19}$ See Atlantic Marine Supreme Court Docket, Supreme Court of the United States, https://www. supremecourt.gov/search.aspx?filename=/docketfiles/12-929.htm

${ }^{20}$ Tony Mauro, Duke Law Prof's Brief Takes Center Court, National Law Journal (October 9, 2013), http://www.nationallawjournal.com/id=1202622883188/Duke-Law-Profs-Brief-Takes-Center-Court?slreturn=20170108131159.

${ }^{21}$ Transcript of Oral Argument at 12-13, 15-16, 21-22, 48-49, 51, 55-56, Atlantic Marine Const. v. U.S Dist. Court, et al., 571 U.S. ___, 134 S.Ct. 568 (Oct. 9, 2013) (No. 12-929), available at https:// www.supremecourt.gov/oral_arguments/argument_transcripts/12-929_o7kq.pdf. 
Professors Joseph Kearney and Thomas Merrill wrote that "the extent to which non-parties participate in the Court's decision-making process through the submission of amicus curiae ... briefs [represents] a major transformation in Supreme Court practice." 22 With amicus curiae filings now a "standard feature of litigation," 23 the scope and impact of amici at the Supreme Court level has increasingly been subject to academic scrutiny. A 2005 study found that about $95 \%$ of merits-level cases include the filing of at least one amicus brief. ${ }^{24}$ The same study also found that about one-third of the Court's decisions cite at least one amici. ${ }^{25}$ A 2004 survey of former Supreme Court law clerks revealed that useful amicus briefs were commonly forwarded to the justices, who would then read them. ${ }^{26}$ According to Allison Orr Larsen, "[t]he consensus is that amicus briefs helpfully add factual expertise to the Court's decision making." 27

Journalists have also pinpointed how certain individuals have increasingly specialized in Supreme Court practice and the filing of amicus curiae briefs. ${ }^{28}$ Adam Feldman and Alexander Kappner completed the most recent comprehensive study in this regard. ${ }^{29}$ Analyzing 93,000 cert petitions between 2001 and 2015, Feldman and Kappner observed that the Supreme Court only accepts about $5 \%$ of the petitions it receives. ${ }^{30}$ However, among the 17 cases with the most cert stage amicus filings, nine of the 17 petitions were accepted for review. ${ }^{31}$ In addition, the small group of leading Supreme Court practitioners involved in petitioner and respondent filings overlapped considerably with the most successful cert stage amici filings. ${ }^{32}$

While the Supreme Court has generally been amenable to the filing of amicus briefs, ${ }^{33}$ the increased appearance of amici at the Supreme Court has also

\footnotetext{
${ }^{22}$ Joseph D. Kearney \& Thomas W. Merrill, The Influence of Amicus Curiae Briefs on the Supreme Court, 148 U. Pa. L. Rev. 743, 744 (2000).

${ }^{23}$ Michael K. Lowman, The Litigating Amicus Curiae: When Does the Party Begin after the Friends Leave?, 41 Ам. U. L. Rev. 1243 (1992).

${ }^{24}$ Ryan J. Owens \& Lee Epstein, Amici Curiae during the Rehnquist Years, 89 JudicAture 127, 128 (2005).

${ }^{25} \mathrm{Id}$.

${ }^{26}$ Kelly J. Lynch, Best Friends? Supreme Court Law Clerks on Effective Amicus Curiae Briefs, 20 J.L. \& Pol. 33, 45 (2004).

${ }^{27}$ Allison Orr Larsen, The Trouble with Amicus Facts, 100 VA. L. REv. 1757 (2014). See also Allison Orr Larsen \& Neal E. Devins, The Amicus Machine, 102 VA. L. Rev. 1901 (2016).

${ }^{28}$ Joan Biskupic, Janet Roberts, \& John Shiffman, At America's Court of Last Resort, a Handful of Lawyers Now Dominates the Docket, ReuTERs (Dec. 8, 2014), http://www.reuters.com/investigates/special-report/scotus/.

${ }^{29}$ Adam Feldman \& Alexander Kappner, Finding Certainty in Cert: An Empirical Analysis of the Factors Involved in Supreme Court Certiorari Decisions from 2001-2015, 62 VILL. L. REv. (forthcoming 2017).

${ }^{30} \mathrm{Id}$.

${ }^{31} \mathrm{Id}$.

${ }^{32} I d$.

${ }^{33}$ Ed. R. Hayden \& Kelly Fitzgerald Pate, The Role of Amicus Briefs, 70 Alabama Lawyer 115, 118 (2009).
} 
been criticized on numerous grounds. Samuel Krislov detailed how the amicus brief has shifted "[f]rom friendship to advocacy." 34 Andrew Frey asked if amicus briefs were becoming a "nuisance." ${ }^{35}$ Michael Rustad and Thomas Koenig probed how "junk social science" can result in "selective distortion in amicus briefs." Rebecca Haw argued that certain "reliance on amicus briefs makes Supreme Court antitrust adjudication analogous to administrative notice-and-comment rulemaking." 37

A handful of published legal decisions have also been critical of amicus brief filings. Judge Posner penned the most pointed critique in Ryan v. Commodity Futures Trading Commission. ${ }^{38}$ In relevant part:

The vast majority of amicus curiae briefs are filed by allies of litigants and duplicate the arguments made in the litigants' briefs, in effect merely extending the length of the litigant's brief. Such amicus briefs should not be allowed. ... An amicus brief should normally be allowed when a party is not represented competently or is not represented at all, when the amicus has an interest in some other case that may be affected by the decision in the present case (though not enough affected to entitle the amicus to intervene and become a party in the present case), or when the amicus has unique information or perspective that can help the court beyond the help that the lawyers for the parties are able to provide. Otherwise, leave to file an amicus curiae brief should be denied. ... In an era of heavy judicial caseloads and public impatience with the delays and expense of litigation, we judges should be assiduous to bar the gates to amicus curiae briefs that fail to present convincing reasons why the parties' briefs do not give us all the help we need for deciding the appeal. ${ }^{39}$

In Long v. Coast Resorts, Judge Hunt described the gatekeeper function when considering whether to accept the filing of an amicus brief: "This Court recognizes that it has the power to permit the appearance as amicus curiae. However, it also has the power to reject it. There is no inherent right to file an amicus curiae brief with the Court. It is left entirely to the discretion of the Court." ${ }^{" 40}$ Even a sport law case mentioned an amicus brief. ${ }^{41}$ In New England Patriots Football

\footnotetext{
${ }^{34}$ Samuel Krislov, The Amicus Brief: From Friendship to Advocacy, 72 Yale L. J. 694 (1963).

${ }^{35}$ Andrew Frey, Amici Curiae: Friends of the Court or Nuisances?, 33 Litig. 5 (2006).

${ }^{36}$ Michael Rustad \& Thomas Koenig, The Supreme Court and Junk Social Science: Selective Distortion in Amicus Briefs, 72 N.C. L. Rev. 91 (1993).

${ }^{37}$ Rebecca Haw, Amicus Briefs and the Sherman Act: Why Antitrust Needs a New Deal, 89 TEx. L. REV. 1247 (2011).

${ }^{38} 125$ F.3d 1062 (7th Cir. 1997).

${ }^{39} \mathrm{Id}$. at 1063-1064.

4049 F.Supp.2d 1177, 1178 (D. Nev. 1999).

${ }^{41}$ New England Patriots Football Club v. Univ. of Colorado, 592 F.2d 1196 (1st Cir. 1979).
} 
Club v. University of Colorado, a contract law dispute involving a football coach, the First Circuit referenced a "self-serving statement in [an] amicus brief."

\title{
Supreme Court Amicus Brief: An Example
}

Subject to non-substantive formatting changes in order the comply with certain Journal of Legal Aspects of Sport guidelines, the following content includes, in full, my certiorari stage United States Supreme Court amicus brief filed November 4, 2016, in the Christie, et al. v. National Collegiate Athletic Association, et al. sports betting litigation. The Supreme Court considered the writ of certiorari during a January 13, 2017, conference. On January 17, 2017, the Supreme Court invited the Solicitor General to file a brief explaining the government's view of the case, suggesting the justices had some level on interest in the case. On June 27, 2017, the Supreme Court agreed to hear the case during the October 2017 term.

\section{Cover Page}

\author{
Nos. $16-476$ \\ In the Supreme Court of the United States \\ Christopher J. Christie, Governor of New Jersey, et al., \\ Petitioners, \\ $\mathrm{v}$. \\ National Collegiate Athletic Association, et al., \\ Respondents. \\ On Petitions for Writ of Certiorari to the \\ United States Court of Appeals for the Third Circuit \\ Brief of Professor Ryan M. Rodenberg as \\ Amicus Curiae in Support of Petitions for \\ Writ of Certiorari
}

November 4, 2016

\section{Table of Contents}

Table of Authorities

Interest of the Amicus Curiae

Summary of Argument

${ }^{42} I d$., at 1200.

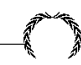


Argument

I. The Professional and Amateur Sports Protection Act Unconstitutionally Delegates Regulatory Power to Sports Leagues in Violation of the Private Nondelegation Doctrine

II. The Professional and Amateur Sports Protection Act's Grant of Injunctive Relief to Non-Litigant Third Parties Is Unconstitutional Under Article III's "Cases" or "Controversies" Requirement

Conclusion

\section{Table of Authorities}

Cases

Allen v. Wright, 468 U.S. 737 (1984)

Buckley v. Valeo, 424 U.S. 1 (1976)

Califano v. Yamasaki, 442 U.S. 682 (1979)

Carter v. Carter Coal Co., 298 U.S. 238 (1936)

Dep't of Transp. v. Ass'n of Am. R.R., 575 U.S. , 135 S. Ct. 1225 (2015)

Doe v. Nat'l Bd. of Medical Examiners, 199 F.3d 146 (3d Cir. 1999)

Greater New Orleans Broadcasting Ass'n, Inc. et al. v. United States, 527 U.S. 173 (1999)

J. W. Hampton, Jr., \& Co. v. United States, 276 U.S. 394 (1928)

Kowalski v. Tesmer, 543 U.S. 125 (2004)

Lujan v. Defenders of Wildlife, 504 U.S. 555 (1992)

Mistretta v. United States, 488 U.S. 361 (1989)

Sunshine Anthracite Coal Co. v. Adkins, 310 U.S. 381 (1940)

Whitman v. Am. Trucking Ass'ns, 531 U.S. 457 (2001)

Constitution and Statutes

U.S. Const. Art. I, $\S 1$

U.S. Const. Art. III, $\S 2$, cl. 1

15 U.S.C. $\S 3001(\mathrm{a})(1)$

28 U.S.C. $\S 3701$ et seq.

28 U.S.C. $\$ 3702$

28 U.S.C. $\S 3703$

31 U.S.C. $\S 5361$ et seq.

Other Authorities

Bill Bradley, The Professional and Amateur Sports Protection Act - Policy Concerns Behind Senate Bill 474, 2 Seton Hall J. of Sport L. 5 (1992)

Lawrence P. Ferazani 30(b)(6) Deposition, NCAA et al. v. Christie et al. No. 3:12-cv-4947 (MAS) (LHG) (Nov. 5, 2012)

Christine Hurt, Regulating Public Morals and Private Markets: Online Securities Trading, Internet Gambling, and the Speculation Paradox, 86 B. U. L. REV. 371 (2006)

Letter from Rick Buchanan (NBA), Elsa Kircher Cole (NCAA), William Daly (NHL), Tom Ostertag (MLB) \& Jeffrey Pash (NFL) to Members of the House Financial Services Committee (May 31, 2007)

Letter from Rick Buchanan (NBA), Elsa Kircher Cole (NCAA), William Daly (NHL), Tom Ostertag (MLB) \& Jeffrey Pash (NFL) to Members of Congress (July 30, 2007) 
Letter from W. Lee Rawls, Assistant Attorney General, Department of Justice, to the Honorable Joseph R. Biden, Jr., Chairman, Committee on the Judiciary (Sept. 24, 1991)

Order on Plaintiffs' Application for a Temporary Restraining Order, NCAA et al. v. Christie et al. No. 3:14-cv-14-6450 (MAS) (LHG) (Oct. 24, 2014)

Thomas Ostertag 30(b)(6) Deposition, NCAA et al. v. Christie et al. No. 3:12-cv4947 (MAS) (LHG) (Nov. 6, 2012)

Plaintiffs' Memorandum of Law in Opposition to Defendants' Motion to Dismiss the Complaint, NCAA et al. v. Christie et al. No. 3:12-cv-4947 (MAS) (LHG) (Oct. 1, 2012)

Plaintiffs' Reply Brief in Support of Their Motion for Summary Judgment and..., NCAA et al. v. Christie et al. No. 3:12-cv-4947 (MAS) (LHG) (Dec. 12, 2012)

Professional and Amateur Sports Protection Act: Hearing on H.R. 74 Before the Subcommittee on Economic and Commercial Law of the House of Representatives Committee on the Judiciary, 102d Congress (Sept. 12, 1991)

Prohibiting State-Sanctioned Sports Gambling: Hearing on S. 473 and S. 474 Before the Subcommittee on Patents, Copyrights \& Trademarks of the Senate Committee on the Judiciary, 102d Congress (June 23, 1991)

Response Brief of Plaintiffs-Appellees, NCAA et al. v. Christie et al., (June 7, 2013) No. 13-1713, 13-1714, 13-1715

I. Nelson Rose and Rebecca Bolin, Game On for Internet Gambling: With Federal Approval, States Line Up to Place Their Bets, 45(2) ConN. L. Rev. 653 (2012)

S. Rep. 102-248, Professional and Amateur Sports Protection, Nov. 26, 1991 Adam Silver, "Legalize Sports Betting," New York Times (Nov. 14, 2014)

\section{$\underline{\text { Interest of the Amicus Curiae }}^{43}$}

Ryan M. Rodenberg works as an associate professor at Florida State University with a research focus on forensic sports law analytics. He has published a number of academic and nonacademic articles about sports gambling and testified before Congress regarding the same. He has a strong interest in ensuring that the nation's sports gambling laws comply with the Constitution.

\section{Summary of Argument}

The Professional and Amateur Sports Protection Act of 1992, 28 U.S.C. § 3701 et seq. ("PASPA") unconstitutionally delegates regulatory power to sports leagues in violation of the private nondelegation doctrine. PASPA also violates Article III's "cases" or "controversies" requirement by allowing injunctive relief to nonlitigant third parties.

Prior to its enactment, the Department of Justice ("DOJ") opposed PASPA on two grounds. Letter from W. Lee Rawls, Assistant Attorney General, Department of Justice, to the Honorable Joseph R. Biden, Jr., Chairman, Committee on

\footnotetext{
${ }^{43}$ Pursuant to Rule 37, amicus curiae certifies that no counsel for a party authored this brief in whole or in part, and no party or counsel for a party made a monetary contribution intended to fund the preparation or submission of this brief. No one other than amicus curiae made a monetary contribution to the preparation or submission of this brief. Counsel for all parties were timely notified more than ten days before the filing of this brief. Letters from the parties consenting to the filing of the amicus curiae brief have been filed with the Clerk of the Court.
} 
the Judiciary (Sept. 24, 1991). First, the DOJ concluded that PASPA raised "federalism issues." Id. Second, the DOJ found it "particularly troubling that [PASPA] would permit enforcement of its provisions by sports leagues." Id. Petitioners comprehensively address the DOJ's first concern in their petitions for a writ of certiorari.

Amicus curiae addresses the DOJ's second concern here.

PASPA violates well-established constitutional limits regarding the legislative delegation of regulatory power as set forth in Carter v. Carter Coal Co., 298 U.S. 238 (1936) and Dep't of Transp. v. Ass'n of Am. R.R., 575 U.S.

S. Ct. 1225 (2015). The Court has made clear that Congress cannot delegate regulatory authority to a private entity. This exact issue was raised in a related context nine years ago by the same five plaintiff sports leagues in this case. The private plaintiffs here - the National Collegiate Athletic Association ("NCAA"), National Basketball Association ("NBA"), National Football League ("NFL"), National Hockey League ("NHL"), and Office of the Commissioner of Baseball ("MLB") (collectively "Plaintiff Sports Leagues") — cautioned Congress that a draft bill aimed at relaxing internet gambling restrictions with an opt-out clause for sports betting could "be challenged in U.S. courts on the grounds that Congress has unconstitutionally delegated its lawmaking power (to ban Internet gambling) to private parties (commissioners of various sports leagues and conferences)." Letter from Rick Buchanan (NBA), Elsa Kircher Cole (NCAA), William Daly (NHL), Tom Ostertag (MLB) \& Jeffrey Pash (NFL) to Members of the House Financial Services Committee (May 31, 2007). Similarly, PASPA's outsourcing of regulatory authority to sports leagues runs counter to the private nondelegation doctrine. In sum, Congress has given private sports leagues a substantial - and unconstitutional - role in deciding what types of sports gambling are lawful.

PASPA, as interpreted by lower courts, also unconstitutionally allows injunctive relief to non-litigant third parties in contravention of Article's III's "cases" or "controversies" requirement. The District Court's self-reversal on this point in connection with New Jersey's challenged sports betting law renders PASPA inconsistent with Lujan v. Defenders of Wildlife, 504 U.S. 555 (1992) and other Court precedent regarding standing, especially within the narrow context of an injunction. In this case, the District Court initially granted injunctive relief to the Plaintiff Sports Leagues in a manner "limited to the application that's been put before the [c]ourt which is limited to the plaintiffs' games." Order on Plaintiffs' Application for a Temporary Restraining Order, NCAA et al. v. Christie et al. No. 3:14-cv-14-6450 (MAS) (LHG) (Oct. 24, 2014). But hours later, with no citation to authority and no supplemental briefing, the District Court reversed itself and ruled, in relevant part: "The scope of restraints is NOT limited to the games sponsored by the plaintiffs' leagues" (emphasis in original). Id. This sua sponte change extended PASPA-derived injunctive relief to all sports leagues, not just the leagues represented in the action before the court. Such extensions are unconstitutional.

Deciding whether PASPA is constitutionally valid on the grounds discussed by amicus curiae provides the Court with two alternative legal bases to decide this case. These alternatives differ markedly from the arguments set forth by the Petitioners. 
For these reasons, the Court should grant the petitions for writ of certiorari.

\section{$\underline{\text { Argument }}$}

I. The Professional and Amateur Sports Protection Act Unconstitutionally Delegates Regulatory Power to Sports Leagues in Violation of the Private Nondelegation Doctrine

Prior to PASPA's enactment, the DOJ told Congress that it was "particularly troubling that [PASPA] would permit enforcement of its provisions by sports leagues." Letter from W. Lee Rawls, Assistant Attorney General, Department of Justice, to the Honorable Joseph R. Biden, Jr., Chairman, Committee on the Judiciary (Sept. 24, 1991). In 2007, the Plaintiff Sports Leagues communicated a related concern to Congress, expressing reservations about private parties' role in banning gambling. The year after the Unlawful Internet Gambling Enforcement Act of 2006 ("UIGEA") was enacted, Congress considered a House bill (H.R. 2046) that would roll back some of UIGEA's restrictive internet gambling provisions. 31 U.S.C. $\S 5361$ et seq.

Included in the draft bill was an opt-out clause permitting sports leagues to prohibit internet gambling on affiliated sporting events. The NFL, MLB, NBA, NHL, and NCAA - the same five plaintiffs here-sent a May 31, 2007 letter to Congress in opposition to H.R. 2046 generally and the opt-out provision specifically. In relevant part, the Plaintiff Sports Leagues wrote: "[T]he optouts are subject to challenge in U.S. courts on the grounds that Congress has unconstitutionally delegated its lawmaking power (to ban Internet gambling) to private parties (commissioners of various sports leagues and conferences)." Letter from Rick Buchanan (NBA), Elsa Kircher Cole (NCAA), William Daly (NHL), Tom Ostertag (MLB) \& Jeffrey Pash (NFL) to Members of the House Financial Services Committee (May 31, 2007).

The apparent rationale of the Plaintiff Sports Leagues in their May 31, 2007, letter to Congress is the same rationale underpinning amicus curiae's briefthrough PASPA, Congress has unconstitutionally delegated its legislative power over sports gambling to private sports leagues. ${ }^{44} \mathrm{Via}$ the deputizing provisions of PASPA, Congress has effectively delegated the authority to shape the contours

\footnotetext{
${ }^{44}$ Senator Bill Bradley explained how PASPA is tethered to Congressional lawmaking efforts: "To aid in the enforcement of this legislative goal of proscribing sports betting, [PASPA] authorizes parties such as the $[D O J]$ and any affected sports organization to seek injunctive relief against an infringement of the act." Bill Bradley, The Professional and Amateur Sports Protection Act Policy Concerns Behind Senate Bill 474, 2 Seton Hall J. of Sport L. 5, 9 (1992).
} 
of federal sports gambling policy to private actors (sports leagues), with PASPAdeputized sports leagues left to choose whether to regulate or not according to their own interests. ${ }^{45}$

The grant of opt-in regulatory power under PASPA is functionally analogous to the proposed opt-out clause the Plaintiff Sports Leagues argued against in their joint 2007 letter to Congress. PASPA's conferral of broad sports gambling regulatory power to private sports leagues is also in direct conflict with Congress' finding that: "the States should have the primary responsibility for determining what forms of gambling may legally take place within their borders." 15 U.S.C. $\S$ 3001(a)(1). ${ }^{46}$ Under PASPA, sports leagues have priority over States in this regard.

Others have expressed concerns closely tied to those of the DOJ and Plaintiff Sports Leagues. According to Senator Chuck Grassley: "[PASPA] would prohibit purely intrastate activities. The Federal Government also has never authorized private parties to enforce such restrictions against the States. This legislation would do so." S. Rep. 102-248, Professional and Amateur Sports Protection, Nov. 26, 1991, p. 12. Two commentators concurred: "PASPA is vulnerable to constitutional challenges based on its procedural mechanisms ... PASPA is a facially unprecedented law, giving sports organizations the ability to trump state legislators." I. Nelson Rose and Rebecca Bolin, Game On for Internet Gambling: With Federal Approval, States Line Up to Place Their Bets, 45(2) CONN. L. REV. 653, 687 (2012).

The purported purpose of PASPA was "to prohibit sports gambling conducted by, or authorized under the law of, any State or other governmental entity." S. Rep. 102-248, Professional and Amateur Sports Protection, Nov. 26, 1991, p. 3. PASPA also aimed to "keep sports gambling from spreading." Id. Through the empowerment of certain sports leagues and the inclusion of a number of exemptions, Congress left PASPA's reach to be determined, at least in part, by sports league executives. As a result, some forms of sports gambling covered by PASPA have been challenged, while other types have been ignored. Congress

\footnotetext{
${ }^{45}$ Congressional testimony from Oregon State Lottery director James J. Davey described PASPA's delegation as follows: "While it is true the federal government has regulated interstate wagering, the federal government has not attempted to tell the states what they can do within their own borders. This legislation would do precisely that. Moreover, it would delegate to private parties, the professional sports leagues, the power to enforce these restrictions against the sovereign states. If Congress can enact this legislation, what is to stop it from prohibiting state lotteries altogether in favor of a national lottery, or of authorizing other private parties to enforce their 'special interests' against the states." Professional and Amateur Sports Protection Act: Hearing on H.R. 74 Before the Subcommittee on Economic and Commercial Law of the House of Representatives Committee on the Judiciary, 102d Congress (Sept. 12, 1991). Congressional testimony from Massachusetts State Lottery director Thomas O'Heir was in accord: "[PASPA] would delegate to private parties the power to enforce ... restrictions against the States." $I d$.

${ }^{46}$ This finding is consistent with a prior statement made by executives from the Plaintiff Sports Leagues: "whether you think gambling liberalization is a bad idea or a good one, the policy judgments of State legislatures and Congress must be respected." Letter from Rick Buchanan (NBA), Elsa Kircher Cole (NCAA), William Daly (NHL), Tom Ostertag (MLB) \& Jeffrey Pash (NFL) to Members of Congress (July 30, 2007).
} 
could have opted for a uniform federal ban on sports gambling and sought to preempt any conflicting state law. Congress could have also left PASPA enforcement exclusively to the DOJ. But Congress selected neither option, pushing PASPA into unconstitutional grounds vis-à-vis the private nondelegation doctrine.

Article I states that "[a]ll legislative Powers herein granted shall be vested in a Congress of the United States." U.S. Const. Art. I, § 1. The resulting nondelegation doctrine includes two prongs: (i) the public nondelegation doctrine and (ii) the private nondelegation doctrine. Under the public nondelegation doctrine, "Congress must 'lay down by legislative act an intelligible principle to which the person or body authorized to [act] is directed to conform." Whitman v. Am. Trucking Ass'ns, 531 U.S. 457, 472 (2001) quoting J. W. Hampton, Jr., \& Co. v. United States, 276 U.S. 394, 409 (1928) ("delegations of rulemaking authority conveyed to an agent under the limits of an intelligible principle are allowed; those without the limits of an intelligible principle are prohibited").

The Court has largely allowed Congress to delegate rulemaking power to other government actors. However, since Carter v. Carter Coal Co., 298 U.S. 238, 311 (1936), the Court has made clear that delegation of regulatory power to private, non-governmental entities is prohibited as "denial of rights safeguarded by the due process clause of the Fifth Amendment." In Carter Coal, the Court explained that a delegation to a private party "is legislative delegation in its most obnoxious form; for it is not even delegation to an official or an official body, presumptively disinterested, but to private persons whose interest may be and often are adverse to the interests of others in the same business." Id.; see also, Mistretta v. United States, 488 U.S. 361, 373 n.7 (1989) (challenged statute was permissible because it did not "delegate regulatory power to private individuals"). The only exception to this rule is if the private entities "function subordinately" to the government. Sunshine Anthracite Coal Co. v. Adkins, 310 U.S. 381, 399 (1940).

The Court recently revisited this issue in Dep't of Transp. v. Ass'n of Am. R.R., 575 U.S. _, 135 S. Ct. 1225 (2015). There, the Court reversed a decision finding a violation of the private nondelegation doctrine on the basis that the regulator in question, Amtrak, was a government actor, not a private party. In so doing, the Court reaffirmed the nondelegation doctrine as applied to private parties. $I d$. at 1252 ("the 'private nondelegation doctrine' is merely one application of the provisions of the Constitution that forbid Congress to allocate power to an ineligible entity, whether governmental or private") (Justice Thomas concurring). Relatedly, when delegating to private parties, "there is not even a fig leaf of constitutional justification." Id. at 1237 (Justice Alito concurring). Further, "[p]rivate entities are not vested with 'legislative Powers. Nor are they vested with the executive Power,' which belongs to the President." Id. (internal citations omitted). And, "[b]y any measure, handing off regulatory power to a private entity is 'legislative delegation in its most obnoxious form." Id. at 1238, quoting Carter Coal, 298 U.S. at 311.

The rationale underpinning the private nondelegation doctrine relates to the Appointments Clause barring private actors from exercising "significant authority pursuant to the laws of the United States." Buckley v. Valeo, 424 U.S. 
1, 126 (1976). Through PASPA, private sports leagues are empowered to file suit against States and individuals. Such power is significant, as it carries with it the ability to shape sports gambling laws nationwide. The Plaintiff Sports Leagues have sued under PASPA three times-once against Delaware Governor Markell and twice against New Jersey Governor Christie. In sum, PASPA gives sports leagues a substantial role in determining what types of sports betting are either legal or illegal. For these reasons, PASPA is unconstitutional vis-à-vis the private nondelegation doctrine.

The lessons of Carter Coal and Ass'n of Am. R.R. are directly applicable to the sports gambling context. Through PASPA, Congress has delegated regulatory power to private sports leagues on par with that of the DOJ. Since enactment, only deputized sports leagues have initiated PASPA lawsuits. The regulatory equality between the DOJ and private sports leagues under PASPA differs markedly from the subservient role permitted under Adkins. With many sports leagues opting to monetize sports gambling through the sale of gambling-related data (including no fewer than two of the Plaintiff Sports Leagues), such leagues can reasonably be viewed as actual or potential competitors to States like New Jersey.

Plaintiff Sports Leagues, like other sports associations, are private actors for purposes of the private nondelegation doctrine. However, if private sports leagues were somehow found to be a governmental entity, PASPA's lack of an "intelligible principle" would still render the statute unconstitutional under the public nondelegation doctrine in Whitman and J. W. Hampton. There are three reasons for this.

First, with at least two of the five Plaintiff Sports Leagues actively monetizing sports gambling, the Plaintiff Sports Leagues' interests are adverse to the very entities PASPA's regulatory scheme attaches-New Jersey and other States seeking to regulate and tax sports betting under state law. With today's technology-fueled revenue-generating gambling opportunities for sports leagues, New Jersey and the Plaintiff Sports Leagues are actual or potential competitors. Indeed, the Plaintiff Sports Leagues posited that they have a proprietary interest in "the degree to which others derive economic benefits from their own games." Response Brief of Plaintiffs-Appellees at 18, NCAA et al. v. Christie et al., (June 7, 2013) No. 13-1713, 13-1714, 13-1715. The Plaintiff Sports Leagues also contended that they "have an essential interest in how their games are perceived and the degree to which their sporting events become betting events" (emphasis removed). Id. at 13-14.

Second, PASPA included a grandfathering clause that exempted certain States and betting activities from Section 3702's coverage. ${ }^{47}$ Revealingly, PASPA's

\footnotetext{
${ }^{47}$ Under PASPA, in relevant part, it is unlawful for state governments to: "sponsor, operate, advertise, promote, license, or authorize ... [a] betting, gambling, or wagering scheme based ... on one or more competitive games in which amateur or professional athletes participate ... or on one or more performances of such athletes in such games.” 28 U.S.C. $\$ 3702$.
} 
Senate Report was unable to precisely delineate the exact number or identities of the exempt States: "It appears that Nevada, Oregon, Delaware, and possibly a few other states would be exempt from the ban." S. Rep. 102-248, Professional and Amateur Sports Protection, Nov. 26, 1991, p. $11 .{ }^{48}$ Senator Dennis DeConcini, the chair of the subcommittee holding a PASPA hearing, stated that he supported exemptions for Nevada, Delaware, Montana, Oregon, and South Dakota. Prohibiting State-Sanctioned Sports Gambling: Hearing on S. 473 and S. 474 Before the Subcommittee on Patents, Copyrights \& Trademarks of the Senate Committee on the Judiciary, 102d Congress (June 23, 1991). Congress's uncertainty regarding PASPA's scope runs counter to the public nondelegation doctrine's "intelligible principle" requirement. With Congress unaware of PASPA's scope and the DOJ's inaction to date, the regulation of sports wagering nationwide has effectively been left to sports leagues.

Third, Justice Stevens — writing for a unanimous Court in a 1999 decision about the permissibility of certain gambling-related advertising - opined that PASPA "includes a variety of exemptions, some with obscured Congressional purposes." Greater New Orleans Broadcasting Ass'n, Inc. et al. v. United States, 527 U.S. 173, 179 (1999). Justice Stevens posited that the exemptions make the scope of PASPA's $\S 3702$ "somewhat unclear." Id. at 180. Justice Stevens's observations evidence the lack of any "intelligible principle" in PASPA. Unsurprisingly, the regulation of sports betting under PASPA has been uneven and selective.

A review of PASPA enforcement actions is illustrative. Congress concluded PASPA's exemptions reflect a "policy judgment that sports gambling should be strictly contained." S. Rep. 102-248, Professional and Amateur Sports Protection, Nov. 26, 1991, p. 10. Since PASPA's enactment in 1992, sports gambling has not been strictly contained. To date, the DOJ has never initiated a PASPA proceeding against a State or individual in the statute's 24-year history. By contrast, the Plaintiff Sports Leagues have initiated three PASPA lawsuits.

The direction of PASPA's regulatory scheme is also illustrated by the potential PASPA lawsuits that have not been pursued. Other than a 2009 case against Delaware, the DOJ, Plaintiff Sports Leagues, and any number of other sports leagues have opted against filing PASPA lawsuits against grandfathered States now offering sports betting schemes that did not exist at the time of PASPA's enactment. Examples include Nevada and Montana. Likewise, there have not been any PASPA cases filed in connection with recently-enacted fantasy sports laws in Indiana, Mississippi, Virginia, Tennessee, Massachusetts, New York, Missouri, and Colorado involving contests predicated "on one or more performances of ... athletes in ... games.” 28 U.S.C. § 3702.

The Senate Report accompanying PASPA also made clear that its parameters do not depend on relative levels of skill or chance, which States often use as a distinguishing factor in defining gambling: "The prohibition of section

\footnotetext{
${ }^{48}$ Two commentators posited that: "PASPA grandfathers-in sports betting policies in Nevada, Delaware, and almost a dozen other states, while prohibiting states from later legalizing sports betting or expanding the grandfathered operations." I. Nelson Rose and Rebecca Bolin, Game On for Internet Gambling: With Federal Approval, States Line Up to Place Their Bets, 45(2) ConN. L. REv. 653, 686 (2012).
} 
3702 applies regardless of whether the scheme is based on chance or skill, or on a combination thereof." S. Rep. 102-248, Professional and Amateur Sports Protection, Nov. 26, 1991, p. 9. As such, skill-chance considerations should seemingly play no role in PASPA regulatory efforts.

Varied levels of PASPA enforcement have resulted. While the five Plaintiff Sports Leagues were strong supporters of PASPA immediately prior to its enactment, one or more of them may now be experiencing buyer's remorse. Shifting stances on the morality of sports gambling have played a role in PASPA's uneven enforcement. More importantly, some sports leagues are increasingly viewing the massive sports gambling market as an untapped revenue source. ${ }^{49}$ For example, a majority of the Plaintiff Sports Leagues own equity stakes in consumer engagement-enhancing fantasy sports companies. Further, at least two of the Plaintiff Sports Leagues use a third party to sell betting-relevant real-time data to sports gambling operators overseas.

But PASPA, in an ironic twist, may now be a constraint to entrepreneurial sports leagues in this regard. Far from "protecting" sports as PASPA's title implies, PASPA may be inhibiting both game integrity and pecuniary aspects of legal and regulated gambling that benefit sports leagues. The Senate Report accompanying PASPA explained:

The committee would like to make it clear that this bill does not benefit professional sports financially. It does not reserve the right to the leagues to hold their own sports gambling operations. They are clearly prohibited under this bill from instituting their own sports betting scheme. S. Rep. 102-248, Professional and Amateur Sports Protection, Nov. 26, 1991, p. 8.

As such, PASPA can plausibly be viewed as a barrier to a sports league's potential monetization of sports betting domestically. This implication has, in turn, likely contributed to varied levels of PASPA regulatory efforts by sports leagues. All of these concerns derive from Congress's unconstitutional grant of lawmaking power (to regulate sports gambling) to private sports leagues. This results because PASPA allows certain sports leagues to unilaterally opt-in to a regulatory role. When Congress outsourced its lawmaking authority over the permissible scope of state-sponsored sports wagering beyond government actors like the DOJ, the private nondelegation doctrine was violated.

Revealingly, the Plaintiff Sports Leagues pinpointed the private nondelegation doctrine in a 2007 letter to Congress within the context of banning internet gambling. The opt-out clause in the draft bill that the Plaintiff Sports Leagues opposed in 2007 is functionally akin to the opt-in provision in PASPA whereby

\footnotetext{
${ }^{49}$ Indeed, a commentator posited: "Instead of the public's passion for competitive sports driving a complimentary market in sports betting, the gambling industry may create a paying audience for professional sports. This dynamic is most clearly seen in the rise of 'Fantasy Sports' leagues and the corresponding increased demand for television sports programming." Christine Hurt, Regulating Public Morals and Private Markets: Online Securities Trading, Internet Gambling, and the Speculation Paradox, 86 B. U. L. REv. 371, 390 (2006).
} 
sports leagues are permitted to regulate the prevalence of permissible sports gambling in grandfathered and non-grandfathered States and seek injunctive relief against States or individuals. The Plaintiff Sports Leagues cautioned against the unconstitutional delegation of Congressional lawmaking power to private parties in 2007 and amicus curiae cautions against the delegation of regulatory power under PASPA now.

II. The Professional and Amateur Sports Protection Act's Grant of Injunctive Relief to Non-Litigant Third Parties Is Unconstitutional Under Article III's "Cases" or "Controversies" Requirement

The lower courts have extended the scope of PASPA's injunctive relief beyond what is constitutionally permitted under Article III. Potential PASPA plaintiffs fall into two categories: (i) the DOJ or (ii) private sector sports organizations. PASPA's enforcement provision reads as follows:

A civil action to enjoin a violation of Section 3702 may be commenced in an appropriate district court of the United States by the Attorney General of the United States, or by a professional sports organization or amateur sports organization whose competitive game is alleged to be the basis of such violation.” 28 U.S.C. $§ 3703$.

This sub-section of PASPA is straightforward. PASPA is a civil, not criminal, statute. The sole remedy under PASPA is injunctive relief. Only the DOJ or certain sports leagues are entitled to pursue equitable remedies under PASPA. According to the Senate's post-hearing report:

Section 3703 authorizes the U.S. Attorney General, or an amateur or professional sports organization whose games are alleged to be the basis of a violation of Section 3702, to seek an injunction against such violation in the appropriate Federal District Court. S. Rep. 102-248, Professional and Amateur Sports Protection, Nov. 26, 1991, p. 9.

The DOJ is not a plaintiff in this litigation, only the five Plaintiff Sports Leagues are. For the Plaintiff Sports Leagues to sustain the lawsuit generally, they had to comply with Article III and related standing requirements. To do so, the Plaintiff Sports Leagues consistently sought injunctive relief solely on their own behalf. For example, in seeking to seal select documents from the public domain, each individual plaintiff posited that such sealing was necessary to keep certain privileged and sensitive documents from the view of other plaintiffs and third parties, evidencing the individual nature of each sports league's claims. Other examples from the Plaintiff Sports Leagues' briefs are illustrative:

The games on which New Jersey intends to authorize gambling belong to the [Plaintiff Sports Leagues]. They are plaintiffs' games, and defendants do not-indeed, cannot_-claim otherwise. Plaintiffs' Reply Brief in Support of Their Motion for Summary Judgment and ... NCAA et al. v. Christie et al. No. 3:12-cv-4947 (MAS) (LHG) (Dec. 12, 2012).

In PASPA, Congress did not grant a cause of action to remedy some undifferentiated public interest, but granted a right of action only to those 
whose discernable interests PASPA was enacted to protect professional and amateur sports organizations whose own games are the object of a challenged violation. Id.

Plaintiffs have an obvious, undisputed and particularized interest in how their own games will be presented to the public and their fans, including with respect to whether those games will be the basis for state-sponsored sports wagering. Congress agreed, concluding that the spread of state-sponsored sports gambling threatens to harm the integrity of plaintiffs' games. Id.

At no time did any of the Plaintiff Sports Leagues claim they were entitled to injunctive relief beyond the alleged harm each suffered individually. And for good reason. Standing was a threshold issue in the first iteration of this case. The Plaintiff Sports Leagues were granted standing to sue New Jersey in connection with the state's new sports betting law. Sports leagues other than the plaintiff quintet could have filed suit too, but they opted not to. Their absence is dispositive. The very title of PASPA- "Professional and Amateur Sports Protection Act"illustrates why. The statute extends "protection" to sports leagues who may feel individually aggrieved by state-authorized sports wagering not otherwise exempted under PASPA. The Plaintiff Sports Leagues described PASPA this way:
[A]s its very title confirms, PASPA was enacted to protect professional and amateur sports organizations and to grant such organizations a legally protected interest in operating their own sporting events free of the spread of state-sponsored gambling. Plaintiffs' Memorandum of Law in Opposition to Defendants' Motion to Dismiss the Complaint, NCAA et al. v. Christie et al. No. 3:12-cv-4947 (MAS) (LHG) (Oct. 1, 2012), p. 2. (emphasis in original).

This is particularly important, as substantial evidence exists about how sports leagues benefit from legal and regulated sports wagering in the form of enhanced game integrity and certain pecuniary aspects. Indeed, the top executive of one of the Plaintiff Sports Leagues penned a New York Times op-ed in 2014 and argued in favor of a legal and regulated sports wagering framework, including "mandatory monitoring and reporting of unusual betting-line movements." Adam Silver, "Legalize Sports Betting," New York Times (Nov. 14, 2014). ${ }^{50}$ Another executive from one of the Plaintiff Sports Leagues said: "The NFL is in a revenue-generating business. If the NFL believes that sports gambling would allow it to increase its revenue, the NFL would engage in that activity." Lawrence P. Ferazani 30(b)(6) Deposition, NCAA et al. v. Christie et al. No. 3:12-cv-4947 (MAS) (LHG) (Nov. 5, 2012).

\footnotetext{
${ }^{50}$ The integrity-enhancing monitoring of betting data for nefarious statistical fingerprints in a legal and regulated sports gambling market has only recently drawn the attention of the Plaintiff Sports Leagues. For example, three years before one of the Plaintiff Sports Leagues retained a third party to perform such monitoring services, its executive said: "We think the idea that any sportsbook can be helpful to us, again, is completely incorrect. It's almost like saying we'll create a problem and then we'll tell you about it. And how does that benefit us?" Thomas Ostertag 30(b) (6) Deposition, NCAA et al. v. Christie et al. No. 3:12-cv-4947 (MAS) (LHG) (Nov. 6, 2012).
} 
Uninvolved sports leagues should not-indeed, cannot-be subject to any injunction based on Plaintiff Sports Leagues' alleged individualized harms. ${ }^{51}$ The Plaintiff Sports Leagues obtained injunctive relief under PASPA for their own "protection," not for others. Nevertheless, the District Court granted a blanket injunction against New Jersey's offering of sports betting tethered to all sporting events, even those unrelated to the Plaintiff Sports Leagues. This expanded PASPA's scope beyond what is permissible under Article III.

The precise moment when PASPA slipped into unconstitutional grounds on this issue is easily pinpointed in this case. On October 24, 2014, the District Court granted Plaintiff Sports Leagues' motion for a temporary restraining order. Order on Plaintiffs' Application for a Temporary Restraining Order, NCAA et al. $v$. Christie et al. No. 3:14-cv-14-6450 (MAS) (LHG) (Oct. 24, 2014). The District Court judge issued his order from the bench, with the litigants' attorneys taking part via teleconference. At the conclusion of the oral ruling, the official transcript included the following exchange, in relevant part:

THE COURT: Can you hear me?

MR. RICCIO: Yes, I can hear you now. I was unclear whether the scope of your injunction is limited to the plaintiffs' games and not other sporting contests that the plaintiffs have no interest in.

THE COURT: Well, right now the only-the scope is limited to the application that's been put before the Court which is limited to the plaintiffs' games.

MR. RICCIO: That was the clarification I was seeking. Thank you, your Honor.

THE COURT: That's all we have for today counsel. Id.

Hours after the District Court's ruling regarding the permissible scope of injunctive relief under PASPA, and with no citations to authority or supplemental briefing, the District Court proceeded to reverse itself on this point and added the following at the end of its order:

ADDENDUM: Upon further consideration of the question posed by [Mr. Riccio] as to the scope of the temporary restraining order, this court finds that the temporary restraining order restrains the implementing, enforcing, or taking any action pursuant to New Jersey Senate Bill 2460 (P.L. 2015, c. 62), the 2014 Law, and would apply to any lottery, sweepstakes, or other betting, gambling, or wagering scheme based, directly or indirectly, on one or more competitive games in which amateur or professional athletes participate, or are intended to participate, or on

\footnotetext{
${ }^{51}$ A partial list of U.S.-based sports leagues that opted not to pursue PASPA claims against New Jersey include: (i) Major League Soccer; (ii) National Women's Soccer League; (iii) WTA Tour; (iv) ATP World Tour; (v) Women's National Basketball Association; (vi) LPGA Tour; (vii) PGA Tour; (viii) Ultimate Fighting Championships; (ix) NASCAR; (x) United States Olympic Committee; (xi) World Boxing Organization; and (xii) Arena Football League.
} 
one or more performances of such athletes in such games. The scope of restraints is NOT limited to the games sponsored by the plaintiffs' leagues (emphasis in original). $I d$.

The District Court's sua sponte reversal is unconstitutional under Article III, as deciding an issue that the plaintiffs did not raise is barred. Situations like this are tailor-made for analysis under Article III's "cases" or "controversies" requirement. To do otherwise would invite absurd results where a litigant can further claims properly belonging to third parties with no nexus to the litigation. Indeed, the Plaintiff Sports Leagues made this exact point in an earlier legal filing: "If New Jersey had singled out the World Series, for state-sponsored gambling, then only Major League Baseball could sue.” Plaintiffs' Memorandum of Law in Opposition to Defendants' Motion to Dismiss the Complaint, NCAA et al. v. Christie et al. No. 3:12-cv-4947 (MAS) (LHG) (Oct. 1, 2012), p. 15. The Plaintiff Sports Leagues' baseball example is well-reasoned, as it correctly explains why only actual litigants should be permitted to obtain injunctive relief specific to their own particularized injury alleged under PASPA.

Constitutional and prudential standing requirements were enunciated in Lujan $v$. Defenders of Wildlife, 504 U.S. 555 (1992). Constitutional standing derives from Article III's "cases" or "controversies" provision. U.S. Const. Art. III, § 2, cl. 1. Article III standing is established via a three-pronged test: (i) "injury in fact," (ii) "causation," and (iii) "redressability." Lujan, 504 U.S. at 560-61. The plaintiff's injury must be "based in reality." Doe v. Nat'l Bd. of Medical Examiners, 199 F.3d 146, 153 (3d Cir. 1999).

Prudential standing includes self-imposed jurisdictional limits, including "the general prohibition on a litigant raising another person's legal rights." Allen $v$. Wright, 468 U.S. 737, 751 (1984). Relatedly, the plaintiff's injury cannot result from "the independent action of some third party not before the court." Lujan, 504 U.S. at 560. The Court found a narrow exception for third-party standing, but only if the plaintiff and third party have a close relationship and some obstacle prevents the third party from pursuing its own claims. Kowalski v. Tesmer, 543 U.S. 125, 129-130 (2004). Neither Kowalski prong is met here, as the Plaintiff Sports Leagues do not share any close relationship with rival leagues and there are no meaningful obstacles preventing non-litigant sports leagues from asserting their own PASPA claims.

The District Court's broad grant of injunctive relief to non-litigant third parties is particularly troubling given that it occurred within the context of a motion for a temporary restraining order. Injunctive relief "should be no more burdensome to the defendant than necessary to provide complete relief to the plaintiffs." Califano v. Yamasaki, 442 U.S. 682, 702 (1979). The Plaintiff Sports Leagues never claimed that they would be harmed if an operator in New Jersey were to offer state law-compliant intrastate sports wagering on tennis, golf, race car driving, mixed martial arts, or any other sporting event unrelated to the narrow categories of sports associated with the five Plaintiff Sports Leagues.

If the lower courts' ruling is left to stand, the impact would be profound. Future PASPA sports league plaintiffs would seemingly be permitted to obtain sweeping injunctions against States. And non-litigant third party sports leagues could be 
negatively impacted by such blanket injunctions without even being part of the case. Further, sports leagues pursuing beneficial game integrity and pecuniary aspects associated with a lawful sports gambling framework could be prevented from doing so. This would, in turn, lead to "reverse PASPA" lawsuits challenging broad injunctions obtained by an unrelated sports league under PASPA. With several sports leagues - including some of the Plaintiff Sports Leaguesmoving to monetize sports betting more aggressively than others, dueling PASPA-derived lawsuits are inevitable. More broadly, the underlying decision disrupts well-settled principles of justiciability in the federal courts and could be cited as precedent for non-litigant third parties' ability to obtain injunctive relief under certain federal laws similar to PASPA. Finally, given PASPA's regulatory scheme, other States left with a Hobson's choice may follow New Jersey's lead and move to repeal their current sports gambling prohibitions in whole or in part.

\section{Conclusion}

This case is about Congress's ability to bestow sports gambling-related regulatory power under PASPA, not merely whether New Jersey law can be partially repealed to permit sports betting in certain venues. What amicus curiae presents here is an alternative to Petitioners' arguments. Amicus curiae is focused on (i) Congress's unconstitutional delegation of regulatory power to sports leagues (to determine what types of sports gambling are permissible under PASPA) in violation of the private nondelegation doctrine and (ii) the District Court's unconstitutional grant of PASPA injunctive relief to non-litigant third parties in contravention of Article III's "cases" or "controversies" requirement.

The Court should grant the petitions for writ of certiorari.

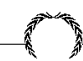

